HABITAT, 31 (2), 2020, 55-63

DOI: 10.21776/ub.habitat.2020.031.2.7

\title{
Efficiency of Palm Oil Companies in Indonesia: A DEA Approach
}

\author{
M. Khairul Anam ${ }^{*}$, Suhartini ${ }^{2}$ \\ ${ }^{1}$ Master's Program of Agricultural Economics, Faculty of Agriculture, Brawijaya University, Malang \\ (65145), Indonesia \\ ${ }^{2}$ Department of Socio Economics, Faculty of Agriculture, Brawijaya University, Malang (65145), \\ Indonesia \\ Received: 4 September 2019; Revised: 13 May 2020; Accepted: 17 July 2020
}

\begin{abstract}
The purpose of this study was to investigate technical, allocative, cost and scale efficiency of palm oil companies in Indonesia. The data used cross sectional data on Indonesian Manufacturing Industries that were collected in the annual surveys by Indonesia's Central of Statistics/BPS for 2015 which is registered under KBLI code 10431. Data envelopment analysis (DEA) is a nonparametric method in operations research and economics for the estimation of production frontiers. It is used to empirically measure productive efficiency of decision making units (DMUs). The input of the palm oil production system are capital, labor, materials, land and energy. While output include industrial product in terms of CPO/PKO and biogas. The finding shows that Riau Island, North Sulawesi and Papua have high score of efficiency in terms of TE, AE, CE and SE, while West Java and Banten province at low level in terms of cost and allocative efficiency.. Nevertheless, on nationwide the score of allocative and cost efficiency still low. Hence, all the input efficiencies still need to be improved, and also reduce cost of production. Beside that, the companies should make an improvement by enhancing management capabilities and improving allocation efficiency.
\end{abstract}

Keyword: efficiency; Data Envelopment Analysis; palm oil companies

\section{How to Cite:}

Anam, M. K., \& Suhartini. (2020). Efficiency of Palm Oil Companies in Indonesia : A DEA Approach. Habitat, 31(2), 55-63. https://doi.org/10.21776/ub.habitat.2020.031.2.7

\section{Introduction}

In several decades the world production of palm oil has increased from 13.5 million metric tons in 1990 to 155.8 million metric tons in 2014 (FAOSTAT, 2017). For reasons of low costs, production efficiency and stability of palm oil makes it the most widely used vegetable oil in the world. Palm oil is ubiquitous in global products, including cosmetics, food, plastics, detergents, biofuels and chemical industry. Then, the performance of palm oil industry growth has certainly been the attention in the global trade market (FAOSTAT, 2017). Therefore, it is important to find how the companies achieved the level of efficiency. According to Kutlar, Ali, and Murat (2013), Alsaleh and Abdul (2018), Barros, Milton and Assaf (2010), stated that the every companies should optimize an achievement to

${ }^{*}$ Correspondence Author

E-mail : anammaduri@gmail.com

Phone: +62812-2590-6422 obtain the highest output possible by preferring the method which uses the composition of input in the most production way and how to minimize the cost.

Indonesia dominates palm oil in the world with total palm oil exports increase in the past six years ranging from 0.08 to 16.06 percent per year (FAOSTAT, 2017). However, the current management of palm oil industry achieved inefficiency and low productivity because only focus on increasing its volume (Tan, Lee, \& Mohamed, 2010), despite the fact that the former are as important.

In addition, this industry has faced high production cost and low productivity, as well as lack of efficient management. It can be shown by derived product and export demand for palm oil being $2.45 \%$ lower, with the volume falling from 25.7 million tons to 25.07 million tons in 2015 (BPS, 2015).

The low productivity of palm oil has been explained by some reasons that could impact their industrial performance. The said reasons include 
their inability to take benefit of economies of scale, the lack of resources in terms of qualified labor and high cost of production (Jalani, Basiron, Darus, Chan, \& Rajanaidu, 2002). Eventually, these reasons thus make the palm oil industry less competitive and inefficient. This condition requires the palm oil producing companies to increase production and productivity continuously, but in Indonesia they located in different regions and different islands.

Palm oil companies in Indonesia spread across 24 provinces and the largest being on Sumatera island. Nevertheless, palm oil production in Sumatra is lower than that of other regions such as Kalimantan. Study of Hasnah, Fleming, and Coelli (2004) found that in Sumatera island still low in technical efficiency reaching $66 \%$. It means that palm oil companies in this region could not technically operate efficiently. This gap is caused by low capital and technology, unpredicted economic situation, inadequate transport infrastructure and low optimality of management (Hamdani, Budiwati, \& Kurniawan, 2016).

Therefore, every company that operates with given technology will have a different level of efficiency compared to companies operating with different technologies. In this present study we include produced good (Crude Palm Oil and Palm Kernel Oil) and biogas as main outputs of palm oil and five inputs such as capital, materials, labor, land, and energy. Each firm, must have purpose to achieve maximum production by input and output combination with the objective being to maximize the average of efficiency in DMU (Decision Making Unit) (Du, Cook, Liang, \& Zhu, 2014).

Some of studies showed that inputs such as capital, materials, labor, land, and energy have linkage on firm efficiency. For instance, in this modern economy, capital is the most important asset in many firms and has directly influence on the performance of firms (Clarke, Seng, \& Whiting, 2011). In addition, capital has associated with labor which technically efficient in palm oil mills (Azman, 2014). In addition to capital, company efficiency is affect by other factors. Sobczyński, Klepacka, Revoredo-Giha, and Florkowski (2015) investigated cost efficiency of dairy farm in leading milk-producing regions in Poland. They found that energy cost, labor and land are statistically significant to farm efficiency in the research area.
Besides, labor as one of input industry also determine the performance, production and efficiency of firm in term of monetary incentives or wages to increase employee effort and productivity (Bonner \& Sprinkle, 2002). Li and Tao (2017) also evaluated the industrial energy efficiency to measure efficiency performance in China accurately in the past decades. The authors find that labor has an important role in the development and evaluation of the industrial energy efficiency and global economic growth.

This paper considers Data Envelopment Analysis (DEA) to estimating technical efficiency (TE), allocative efficiency (AE), cost efficiency (CE), scale efficiency (SE) in differ regions. This study focused on 24 provinces which located in differ regions and island. The reason due to locations is very important for economic interactions and transactions, such as production, trade, investment, export, import, and transfer of knowledge which are limited by distance (Venables, 2001). Therefore, this study addresses specific research question as:

RQ1: How is the technical efficiency (TE), allocative efficiency (AE), cost efficiency (CE), scale efficiency (SE) of Palm oil companies?

\section{Research Methodology}

\subsection{Data}

In this present study, we use cross sectional data on Indonesian Manufacturing Industries that were collected in the annual surveys by Central Bureau of Statistics/BPS for 2015. The government collected the data on a yearly basis industrial production using questionnaire. Coverage of these surveys is basically restricted to medium and large-scale industries, which have at least 20 employees. The total sample contains 1,703 industries and using KBLI (Standard Classification of Indonesian Business Fields) 2015 or ISIC Rev 4. These are spread in 33 provinces, which are in Java Island 1,166 (68.47\%) industries and Outside Java Island 537 (31.53\%) industries. Restricted no geographical indicators, industrial classification detail, presentation of companies age in ranges, and omission of certain data items obtained in the BPS all help to maintain the confidentiality of unit records.

This research is concerned only with palm oil companies in 2015 which is registered under KBLI code 10431. The total numbers of palm oil companies are 693 spread in 24 Provinces in Indonesia with the largest in Riau Province with 
176 Companies and the smallest in South Sulawesi and North Sulawesi with 1 company respectively (Figure 1). Therefore, the location of the palm oil companies that located and spread across several islands is the reason for researcher to be able to further understand the impact of different locations/regions of palm oil companies in various regions in Indonesia.

\subsection{Variable}

The dataset of Annual Manufacturing
Surveys consist of 20 main variables and divided into 5 parts. Part 1 General Information of Companies; Part 2 Expenses; Part 3 Production (Produced Goods); Part 4 Companies Revenue; and Part 5 Capital. In order to measure efficiency, we choose 7 variables and determine five inputs and two outputs based on palm oil processing. In this study we include produced good and palm oil waste as main outputs of palm oil and five inputs such as capital, materials, labor, land, and energy. A brief description is outlined on Table 1 below:

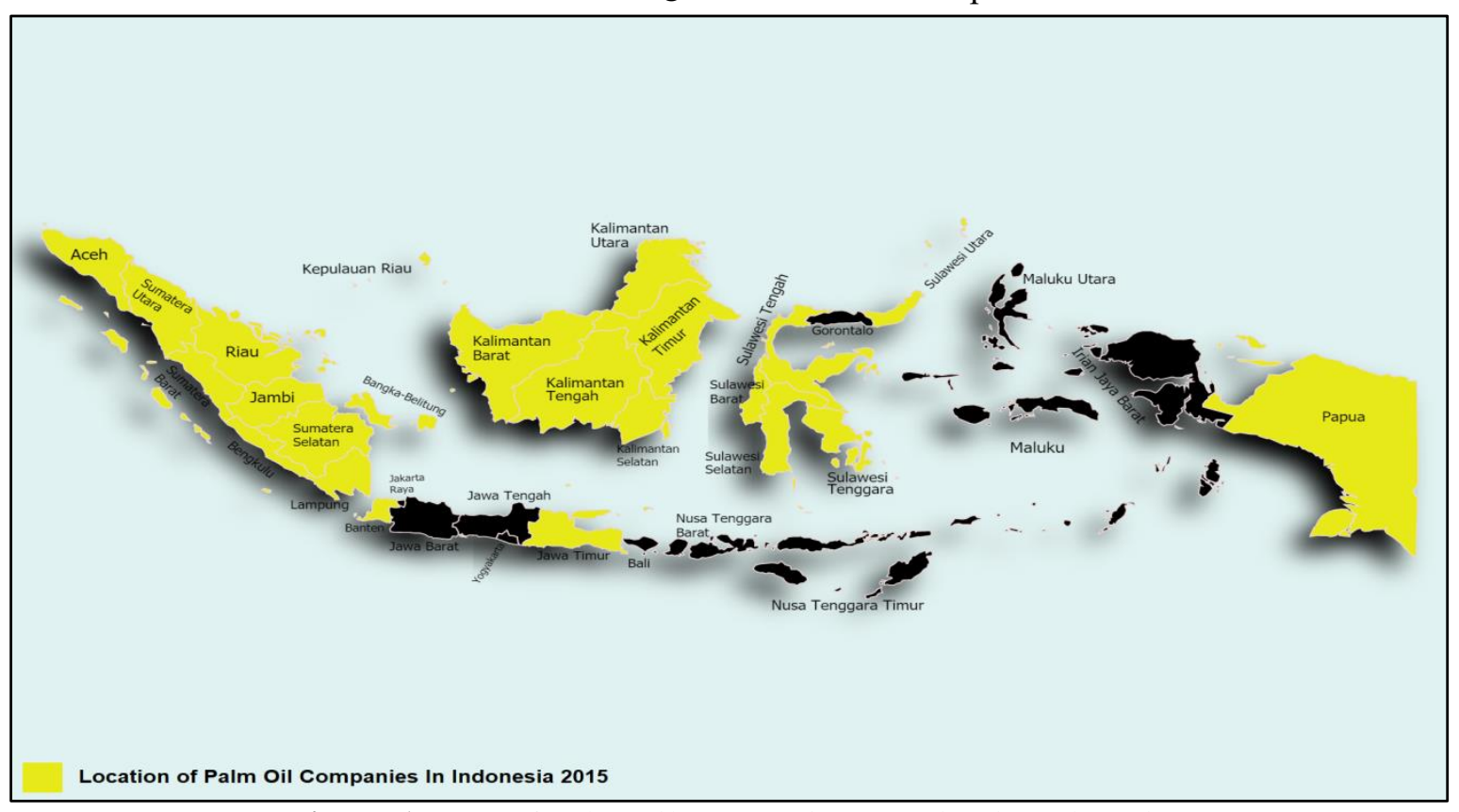

Figure 1. Map of Palm Oil Companies Location in Indonesia

Table 1. A Brief Descriptions of Output and Input Variables

\begin{tabular}{llc}
\hline \multicolumn{1}{c}{ Variables } & \multicolumn{1}{c}{ Descriptions } & Units/Year \\
\hline $\begin{array}{l}\text { Output } \\
\text { Produced Goods }\end{array}$ & $\begin{array}{l}\text { Total value of finished goods produced by the companies in terms } \\
\text { of CPO and PKO } \\
\text { The total quantity of biogas from POME (Palm Oil Mill Effluent) }\end{array}$ & IDR \\
$\begin{array}{l}\text { Input } \\
\text { Capital }\end{array}$ & $\begin{array}{l}\text { Total value of capital that was obtained from the usage of factory, } \\
\text { vehicles, machinery, and equipments. }\end{array}$ & IDR \\
Materials & $\begin{array}{l}\text { Total value of raw materials that use in the beginning of palm oil } \\
\text { processing in terms of FFB (Fresh Fruit Bunches) }\end{array}$ & IDR \\
$\begin{array}{l}\text { Total value of human labor who work in the production process } \\
\text { Land }\end{array}$ & $\begin{array}{l}\text { Total value of land in terms of rent, purchase, and reparation. } \\
\text { Total value of energy that used in palm oil production such as } \\
\text { electricity, fuel, lubricant, coal and gas. }\end{array}$ & IDR \\
\hline
\end{tabular}

\subsection{Data Analysis}

a. Technical Efficiency (TE)

DEA is used to measure the performance of firms or entities (called Decision-Making Units DMUs-) which convert multiple inputs into multiple outputs. Firm efficiency is defined as the ratio of the sum of its weighted outputs to the sum of its weighted inputs. DEA is suitable for the use of both private sector firms and public sector organizations (and even for entities such as regions, countries, etc.) (Shewell and Stephen, 2016). 
According to Jean (2012) the efficiency score of each company is calculated relative to the efficiency frontier. Companies are located on the efficiency frontier have an efficiency score of 1 (or $100 \%$ ). Companies operating below the border have efficiency scores lower than 1 (or 100\%) and therefore have the capacity to improve future performance. Note that no company can be placed above the efficiency limit because they cannot have an efficiency score greater than $100 \%$. Companies located at the border function as benchmarks - or partners - for inefficient companies. These benchmarks (i.e. real companies with real data) are associated with best practices. Therefore DEA is a powerful comparison technique.

We use BCC (Banker, Charnes, \& Cooper, 1984) model to estimate the scores of technical efficiencies compared with CCR (Charnes, Cooper \& Rhodes) due to that is in common used for DEA. The different basic of these model is the treatment of return to scale. BCC model is more flexible than CCR model, because it bases the evaluation based on variable return to scale (VRS) while CCR allows constant return to scale. Consequently, the BCC model is represented below:

$$
\begin{aligned}
& \max _{\varphi, \lambda} \varphi, \\
& \text { s.t. } \\
& \sum_{j=1}^{n} \lambda_{j} x_{i j} \leq x_{i o} \quad i=1, \ldots, m, \\
& \sum_{j=1}^{n} \lambda_{j} y_{r j} \geq \varphi y_{r o} \quad r=1, \ldots, s, \\
& \sum_{j=1}^{n} \lambda_{j}=1, \\
& \lambda_{j} \geq 0 j=1, \ldots, n,
\end{aligned}
$$

From equation 1 above, variables $x_{i j}$ represent the inputs quantity $(i=1, \ldots, m)$ and $y_{r j}$ represent the output quantity $(r=1, \ldots, s)$ for each unit of palm oil company $(j=1, \ldots, n)$. We may formulate to solve the optimisation problem that requires to maximize the potential of output enhancement $\varphi$ across all outputs. The score of efficiency can be interpreted by the reciprocal $1 / \varphi$ that being restricted by an interval $0-1$. For instance, if the score of technical efficiency is 0.5 , it indicates that the output vector $y_{r}$, its means that palm oil company using the vector $x_{i}$, can produce the maximum output by $50 \%$. If the technical efficiency (TE) is 0.8 , this represents that palm oil company using the vector $x_{i}$ can produce the maximum output of technology in each region by $80 \%$.

\section{b. Allocative Efficiency (AE) and Cost Efficiency (CE) \\ We can obtain the score of allocative and} cost efficiency by solving the problem of additional cost minimisation DEA as follow:

$$
\begin{gathered}
\min _{\lambda, x 1} w_{i}^{\prime} x_{i}^{*}, \\
\text { S.t. } \quad-y_{i}+y \lambda \quad 0, \\
x_{i}^{*}-X \lambda \quad 0, \\
\quad N 1^{\prime} \lambda=1 \\
\lambda=0
\end{gathered}
$$

Equation 2 represents $w_{i}$ is a input prices vector for the $i$-th palm oil companies and $x_{i}^{*}$ represents the vector of cost minimizing of input quantities for the $i$-th palm oil companies, given the price of input $w_{i}$ and the level of output $y_{i}$. The cost efficiency is formulated as:

$$
C E=w_{i}^{\prime} x_{i}^{*} / w^{\prime}{ }_{i} x_{i}
$$

Cost efficiency (CE) is the minimum cost ratio to observed cost for the $i$-th palm oil companies. Then, the allocative efficiency (AE) is calculating using:

$$
A E=C E / T E
$$

c. Scale Efficiency (SE)

SE or Scale efficiency can be defined as measurement based on the comparison between VRS (Variable Return to Scale) and CRS (Constant Return to Scale). The ratio efficiency measures these frontiers as follow:

$$
S E=T E_{C R S} / T E_{V R S}
$$

\section{Results and Discussions}

\subsection{Descriptive Statistic}

The data of this research cover 693 palm oil companies from The Annual Manufacturing Survey 2015. There are 24 Provinces and seven variables used here. The seven variables involve two output variables, while the others are inputs variables. The descriptive statistics of the variables are provided in Table 2. As can be seen from the means and standard deviation of all inputs and outputs there are considerable differences among four groups due to value of standard deviation $>100 \%$. It means we shall see 
that the greater variability in the cross section of group allows for more powerful tests.

Table 2 shows that on average palm oil in Indonesia profitable, it can be seen on produced good in terms of CPO or PKO can earn IDR 559 million a year. According to BPS (2015) Palm oil industry in Indonesia increase from year to year. Indonesia produced 32.5 million tons of crude palm oil and exported $80 \%$ of it, earning USD $\$ 18.6$ billion in 2014 , and the production increases become 33.2 million tons of crude palm oil in 2017 and expected to expand at $10 \%$ per year.
However, much of palm oil companies in Indonesia consume excessive raw materials around IDR 371 million, on average. It is caused by the price of FFB (Fresh Fruit Bunches) from farmers is expensive in 2015 by $1,495 \mathrm{IDR} / \mathrm{kg}$. There are some companies not use energy input at all with the minimum value by zero. Because, since 2007 palm oil companies (especially in North Sumatera, West Sumatera, Aceh, Riau and Riau Island) have tried to use biodiesel as a substitute of fuels, coals, etc. through the Ministry of Energy and Mineral Resources and Ministry of Industry have been legalized the palm oil industry to consume biodiesel.

Table 2. Descriptive Statistics

\begin{tabular}{lccrrrr}
\hline \multicolumn{1}{c}{ Variable } & Unit/Year & Obs & \multicolumn{1}{c}{ Mean } & SD & Min & \multicolumn{1}{c}{ Max } \\
\hline $\begin{array}{l}\text { Output (Million IDR) } \\
\text { Produced Good }\end{array}$ & IDR & 693 & 559 & 1010 & 1.02 & 10700 \\
Biogas & M $^{3}$ & 693 & 4.9 & 8.9 & 0.16 & 99.3 \\
$\begin{array}{l}\text { Input (Million IDR) } \\
\text { Capital }\end{array}$ & & & & & & \\
Materials & IDR & 693 & 299 & 5020 & 0.24 & 129000 \\
Labor & IDR & 693 & 371 & 662 & 1.14 & 7370 \\
Land & IDR & 693 & 7.4 & 12.2 & 0.25 & 153 \\
Energy & IDR & 693 & 5.1 & 31.6 & 0 & 492 \\
\hline
\end{tabular}

In terms of land, come back to Table 1, land is defined as the total value of land rent, purchase, and reparation. Some of companies rent a land even purchase it to expand the factory. However, some of them only use the available factory due to budget constraint without add more land either rent or purchae even reparation as can be seen in minimum value by zero.

\subsection{The Result of Efficiency Scores}

Table 3. Total average of efficiency of Palm Oil Companies

\begin{tabular}{lccccc}
\hline \multicolumn{1}{c}{ Provinces } & $\begin{array}{c}\text { Number of } \\
\text { Observation }\end{array}$ & TE & AE & CE & SE \\
\hline Aceh & 22 & 0.963 & 0.662 & 0.639 & 0.978 \\
North Sumatera & 133 & 0.986 & 0.772 & 0.764 & 0.990 \\
West Sumatera & 31 & 0.987 & 0.741 & 0.734 & 0.985 \\
Riau & 176 & 0.985 & 0.725 & 0.716 & 0.989 \\
Riau Island & 2 & 1.000 & 0.871 & 0.871 & 1.000 \\
Jambi & 52 & 0.989 & 0.769 & 0.763 & 0.992 \\
South Sumatera & 35 & 0.994 & 0.820 & 0.817 & 0.990 \\
Bengkulu & 19 & 0.981 & 0.693 & 0.680 & 0.987 \\
Lampung & 12 & 0.975 & 0.675 & 0.659 & 0.982 \\
Bangka Belitung & 16 & 0.968 & 0.722 & 0.701 & 0.982 \\
West Kalimantan & 31 & 0.982 & 0.719 & 0.706 & 0.989 \\
East Kalimantan & 42 & 0.996 & 0.669 & 0.661 & 0.988 \\
Central Kalimantan & 58 & 0.990 & 0.714 & 0.708 & 0.986 \\
South Kalimantan & 25 & 0.989 & 0.731 & 0.725 & 0.995 \\
North Kalimantan & 9 & 0.997 & 0.633 & 0.631 & 0.966 \\
West Java & 4 & 1.000 & 0.592 & 0.392 & 1.000 \\
Banten & 2 & 0.991 & 0.354 & 0.039 & 1.000 \\
Central Sulawesi & 4 & 0.988 & 0.786 & 0.944 & 0.998 \\
\hline
\end{tabular}




\begin{tabular}{lccccc}
\hline Provinces & $\begin{array}{c}\text { Number of } \\
\text { Observation }\end{array}$ & TE & AE & CE & SE \\
\hline South Sulawesi & 1 & 0.937 & 0.504 & 0.472 & 0.967 \\
West Sulawesi & 8 & 0.989 & 0.689 & 0.681 & 0.996 \\
North Sulawesi & 1 & 1.000 & 1.000 & 1.000 & 1.000 \\
South East Sulawesi & 2 & 0.987 & 0.844 & 0.895 & 0.984 \\
Papua & 5 & 1.000 & 0.948 & 0.948 & 0.997 \\
West Papua & 3 & 0.972 & 0.725 & 0.705 & 0.967 \\
\hline Nationwide & 693 & 0.985 & 0.723 & 0.702 & 0.988 \\
\hline
\end{tabular}

The result of TE, $\mathrm{AE}, \mathrm{CE}$ and $\mathrm{SE}$ are reported in Table 3. On average in nationwide, almost all of provinces have high score of Technical Efficiency (TE) because they have efficiency score close to one. However, only 4 provinces which have score equal to one, they are Riau Island, West Java, North Sulawesi and Papua indicating that these provinces technically more efficient compared to others. Industrial growth in Java especially West Java is rapidly developing compared to those outside Java. Infrastructure development such as roads, electricity availability, and human resources are the main causes of industrial lagging outside Java. Although the weather and rainfall are less supportive for the growth of palm oil plants, this industry is still profitable. Even some companies have implemented an ISO 9001:2015 quality management system for the instructions of the ministry of industry. Whereas Riau Island, North Sulawesi and Papua have relatively few palm oil companies, but palm oil in these three regions has recently been developed and introduced in 2005 and the lack of competitors has caused palm oil companies in these regions operate efficiently. In addition, the land tenure system in Papua is generally communal in that land is managed by indigenous people, so the pattern of palm oil industry follows a pattern of communal systems involving institutional systems so that companies and communities could earn profit from this cooperation.

Then, South Sulawesi has a lowest score of TE by 0.937 . Hence, this region has a task for improvement in technical efficiency. The low scores of technical efficiency has been constrained by some factors including the lack of labor that adequately trained, the technological base still low, and the research and development to improve technological process and product still small.

Furthermore, these findings explicitly explain how management in palm oil companies has been efficient in utilizing technology to increase profit. Nevertheless, South Sulawesi should utilize theirs resources more efficiently to generate higher profits and able to compete at national level. Hence, if this region still wants to increase globalized marketplace and become a competitive player, the efforts should be focus on improvement business processes, enhance efficiency through intense competition, adequately trained manpower, and the content of technology investment should be higher. Strengthening of financial, legal infrastructure and physical will further contribute to enhance technical efficiency of palm oil companies in this region.

Although West Java have efficiency score equal to one on technical efficiency, however it has lowest scores of allocative efficiency and cost efficiency with the value of $\mathrm{AE}=0.592$ and $\mathrm{CE}=$ 0.392 including Banten with $\mathrm{AE}=0.354$ and $\mathrm{CE}$ $=0.039$, even if compared to $\mathrm{AE}$ and $\mathrm{CE}$ in the nationwide. In contrast, North Sulawesi and Papua have a highest score of $\mathrm{AE}$ and $\mathrm{CE}$ by 1.000 and 0.948 respectively.

The allocative efficiency (AE) measures the cost reduction proportionally if the palm oil companies choose the feasible input mix given the prices. While CE by itself measures cost reduction proportionally that can be obtained if the palm oil companies are both efficient in terms of allocative and technical efficiency. Furthermore, the score of $\mathrm{CE}$ in Banten shown that the average of palm oil companies could only use resources only $0.4 \%$ to produce the same output level in this year.

Then, the fluctuations in input prices related to the high scores of allocative efficiency which lead to inability of management to make decision in long-term. However, this explanation does not seem for our samples to be the only relevant argument. The costs incurred for purchasing raw materials in the production process are more expensive in Java (West Java and Banten) because palm oil companies is more concentrated in Sumatra and Kalimantan. It is also caused by the price of FFB (Fresh Fruit Bunches) from farmers is expensive in 2015 by $1,495 \mathrm{IDR} / \mathrm{kg}$ on average. 
These scores shown that if the palm oil companies more notice of the relative prices of input when selecting the quantity of inputs, it could reduce costs. Consequently, the allocative efficiency (AE) adds to the degree to which costs can be reduced in the palm oil companies.

According to Foong, et. al (2018) Palm oil companies can achieve economies of scale by enhancing FFB (Fresh Fruit Bunch) in its production. Alsaleh and Abdul (2018) also stated that in orderb to solve the efficiency problem of palm oil companies is by focusing minimize the energy use. It can reduce high production cost and save the energy.

In addition, in terms of scale efficiency (SE), 4 provinces (Riau Island, West Java, Banten and North Sulawesi) has highest score of SE (1.000). This findings indicate that palm companies which located in these regions have scale and optimal size than others to improve companies efficiency.

Based on this finding, we can conclude that Riau Island, North Sulawesi and Papua have high score of efficiency in terms of TE, AE, CE and SE. Hence, palm oil companies in these regions still operate efficient compared with others.

Based on the result we got that Riau province including Riau Island not only become the biggest of palm oil companies in Indonesia, this region also has production capacity amount 6,254 ton per hour. According to Syahza (2012) Riau province has a strategic location to develop palm oil industry even based on land condition and soil fertility CPO productivity in this region amount 3.9 tons per year per hectare.

Besides that, Safrizal (2015) reported in 2015 Riau Province has been developed Renewable energy alternative from POME (Palm Oil Mill Effluent). Development of Biomass Power Plant effluent (POME) in addition to meeting the needs of the local and surrounding electrical energy while addressing environmental pollution due to the waste liquid and solid waste in the area around the plant oil palm. Wastewater treatment capable of preventing the emission of $\mathrm{CH} 4$ gas directly into the atmosphere.

In opposite, Java only has a few of lands for palm oil plantations, because they have a negative impact on the environment and the community also leads to negative social impacts, such as the dispossession of land and poor working conditions on plantations (Dhiaulhaq et al., 2015; Gellert, 2015). Till this year, only a few companies are still operating while its land is in Sumatra. For instance, palm oil land area in Banten Province, it has around 11.000 hectares, however it causes a lack of water, because palm oil plants need quite high of water. Then, if we see from the impact economically, social and environment Java Island has unable to accommodate and do not have the carrying capacity for palm oil plantations.

The Indonesian government also began to expand gardens and palm oil companies in Papua. Even though Papua has a considerable mining wealth, it cannot be a source of daily income for the people. The expansion of oil palm companies in Papua will provide many benefits for the community, including opening employment and partnership systems. Until 2015, based on data from Indonesian's Annual Manufacturing Industry, there have been 8 palm oil companies in Papua.

According to Nelson et al. (2010) stated that although Environmental sustainability of the industry is increasingly coming under scrutiny by growers, palm oil purchasers and various interest groups in Papua and worldwide due to effects of oil palm cultivation on soil, water and the atmosphere, The Papua's oil palm industry has committed itself to certification of environmental stewardship, particularly through the Roundtable on Sustainable Palm Oil. There is thus a need for practical and meaningful indicators of environmental sustainability that are based on a clear understanding of the oil palm agroecosystem, to underpin certification and to guide improvements in management.

\section{Conclusion}

This paper evaluates the efficiency of palm oil companies in Indonesia using Data Envelopment Analysis (DEA). The finding showed that Riau Island, North Sulawesi and Papua have high score of efficiency in terms of TE, $\mathrm{AE}, \mathrm{CE}$ and SE, while West Java and Banten province at low level in terms of cost and allocative efficiency. Therefore, all the input efficiencies still need to be improved, and also reduce cost of production. Beside that, the companies should make an improvement by enhancing management capabilities and improving allocation efficiency and also using technology optimalization due to the pure technology efficiency of the creative companies should be much more increased by applying more new technologies and new business mode.

This study has some limitations. Firstly, we only focus on cross-sectional data for 2015, the efficiency of palm oil companies is not likely to change in the short-term. Second, we only incorporate two desirable output, namely 
produced goods in terms of CPO, $\mathrm{PKO}$, and biogas and five inputs (capital, materials, labor, land, and energy), future research should consider others output and input to better improvement of efficiency.

\section{References}

Alsaleh, M., and Abdul, R. (2018). Determinants of Cost Efficiency of Bioenergy Industry: Evidence from EU28 Countries. Renewable Energy. 127, 746-762.

Azman, I. (2014). The impact of palm oil mills' capacity on technical efficiency of palm oil millers in Malaysia. Oil palm industry economic journal, 14(1), 34-41.

Banker, R. D., Charnes, A., \& Cooper, W. W. (1984). Some models for estimating technical and scale inefficiencies in data envelopment analysis. Management science, 30(9), 1078-1092.

Barros, C.P, Milton, N., and Assaf. (2010). Efficiency in the Greek Insurance Industry. European Journal of Operational Research. 205, 431-436.

Bonner, S. E., \& Sprinkle, G. B. (2002). The effects of monetary incentives on effort and task performance: theories, evidence, and a framework for research. Journal of Accounting, organizations society, 27(4-5), 303-345.

BPS. (2015). Indonesia's Central Statistic Agency. Jakarta, Indonesia.

Clarke, M., Seng, D., \& Whiting, R. H. (2011). Intellectual capital and firm performance in Australia. Journal of Intellectual Capital, 12(4), 505-530.

Dhiaulhaq, A., dr Bruyn, T., Gritten, D., 2015. The use and effectiveness of mediation in forest and land conflict transformation in Southeast Asia: case studies from Cambodia, Indonesia and Thailand. Environ. Sci. Pol. 45, 132-145

Du, J., Cook, W. D., Liang, L., \& Zhu, J. (2014). Fixed cost and resource allocation based on DEA cross-efficiency. European Journal of Operational Research, 235(1), 206-214.

FAOSTAT. (2017). Crops processed, Indonesia and World total Oil palm Production quantity. Retrieved from http://faostat3.fao.org/download/Q/QD/E.
Foong, S.Z.Y., Carmen, K.M.G., Christina, S.S., Denny K.S.Ng. (2018). Input-Output Optimization model for sustainable oil palm plantation development. Sustainable Production and Consumption. 17, 31-46

Gellert, P.K., 2015. Palm oil expansion in Indonesia: land grabbing as accumulation by dispossession. In: Shefner, J. (Ed.), States and Citizens: Accommodation, Facilitation and Resistance to Globalization. Emerald Group Publishing Limited, Bingley, pp. 65-99

Hamdani, N. D. Y., Budiwati, N., \& Kurniawan, A. Y. (2016). Analysis of Household Economic Behavior on the Palm Oil Smallholder in South Kalimantan-Indonesia. International Journal of Research, 15.

Hasnah, Fleming, E., \& Coelli, T. (2004). Assessing the performance of a nucleus estate and smallholder scheme for oil palm production in West Sumatra: a stochastic frontier analysis. Agricultural Systems, 79(1), 17-30. Retrieved from doi:https://doi.org/10.1016/S0308521X(03 )00043-X

Jalani, B., Basiron, Y., Darus, A., Chan, K., \& Rajanaidu, N. (2002). Prospects of elevating national oil palm productivity: a Malaysian perspective. Oil palm industry economic journal, 2(2), 1-9.

Jean-Marc H. (2012). Data Envelopment Analysis (DEA): A pedagogical guide for decision makers in the public sector. IDHEAP Chair of Public Finance. Swiss.

Kutlar, A., Ali, K., and Murat, S. (2013). Determination of the efficiency of the world railway companies by method of DEA and comparison of their efficiency by Tobit analysis. Qual Quant. 47: 3576-3602

Li, M.-J., \& Tao, W.-Q. (2017). Review of methodologies and polices for evaluation of energy efficiency in high energyconsuming industry. Applied Energy, 187, 203-215.

Nelson, P. N., Webb, M. J., Orrell, I., van Rees, H., Banabas, M., Berthelsen, S.,Hoare, M. (2010). Environmental sustainability of oil palm cultivation in Papua New Guinea (Vol. 75): Australian Centre for International Agricultural Research. 
Safrizal, S. (2015). Small renewable energy biogas limbah cair (pome) pabrik kelapa sawit menggunakan tipe covered lagoon solusi alternatif defisit listrik Provinsi Riau. Jurnal Disprotek, 6(1).

Shewell, P ., and Stephen M. (2016). Data Envelopment Analysis in Performance: a critical analysis of the literature. Problems and Persfective in Management. 14 (3).

Sobczyński, T., Klepacka, A. M., Revoredo-Giha, C., \& Florkowski, W. J. (2015). Dairy farm cost efficiency in leading milk-producing regions in Poland. Journal of dairy science, 98(12), 8294-8307.

Syahza, A. (2012). Potensi Pengembangan Industri Kelapa Sawit. Hasil Penelitian MP3EI Universitas Riau.

Tan, H. T., Lee, K. T., \& Mohamed, A. R. (2010). Second-generation bio-ethanol (SGB) from Malaysian palm empty fruit bunch: energy and exergy analyses. Bioresource technology, 101(14), 5719-5727.

Venables, A. J. (2001). Geography and international inequalities: the impact of new technologies. Journal of Industry, Competition and Trade, 1(2), 135-159. 